\title{
Disestablishing “Glacial Lake Speight”, New Zealand? An example for the validity of detailed geomorphological assessment with the study of mountain glaciations
}

Stefan Winkler et al.

Correspondence to: Stefan Winkler (stefan.winkler@uni-wuerzburg.de)

The copyright of individual parts of the supplement might differ from the CC BY 4.0 License. 


\section{Supporting online material}

This PDF file includes additional material illustrating the express report and supporting its conclusions:

\section{Contents:}

S 1 Satellite image depicting the Waimakariri River catchment and its location within New Zealand

S 2 Topographic map of the middle Waimakariri River catchment and its surroundings

S 3 Ground images from the study area showing various sites and features mentioned in the text of the express report and supporting the statements presented within (all images: S.Winkler)

S 4 Oblique aerial images of the study area (all images: S.Winkler) 


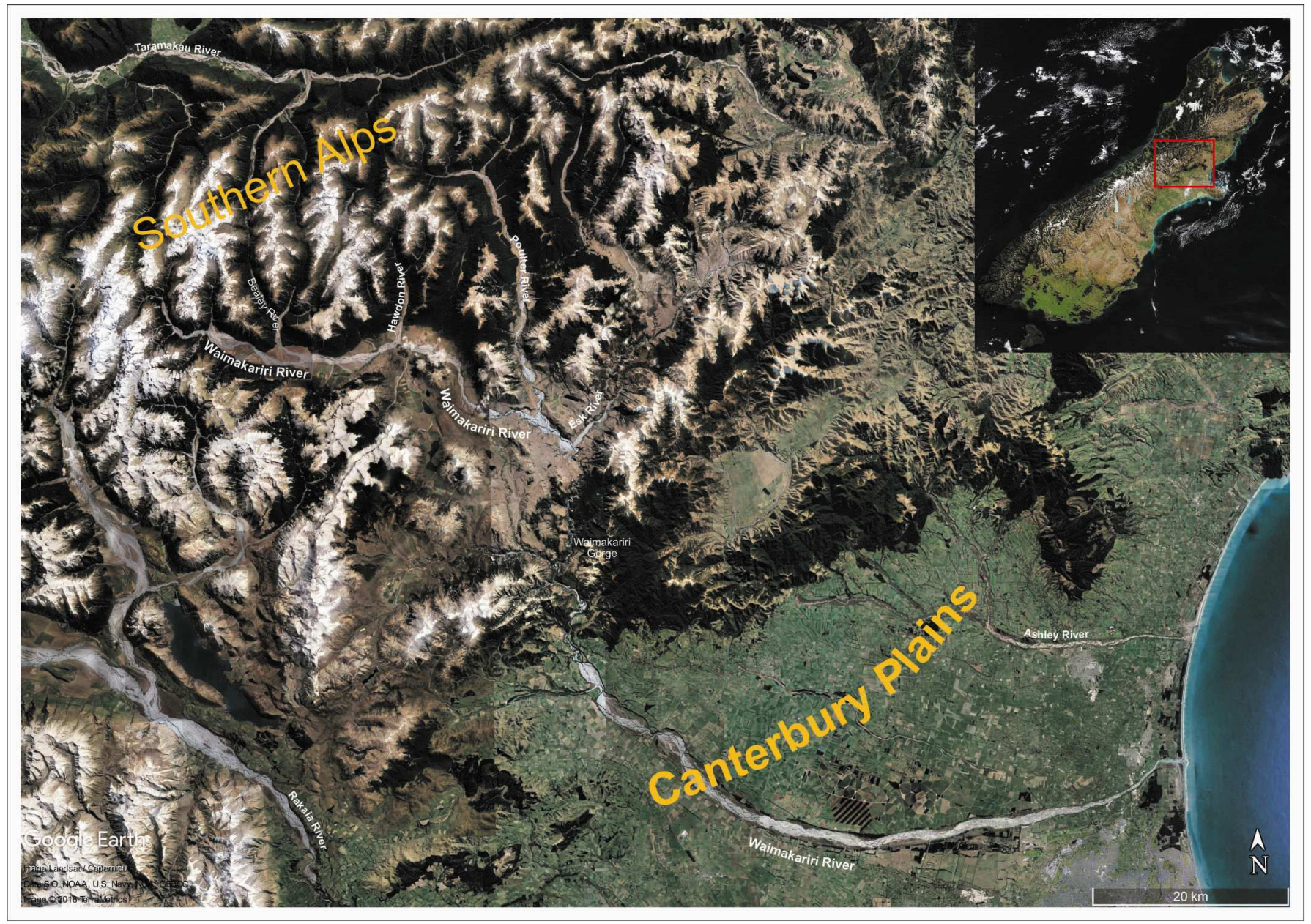

Location of the Waimakariri River catchment within New Zealand. Some other major rivers are indicated, also the Waimakariri Gorge (cf. express report, Figure 1; modified after GoogleEarth and (insert) NASA Earth Observatory, https://earthobservatory.nasa.gov). 


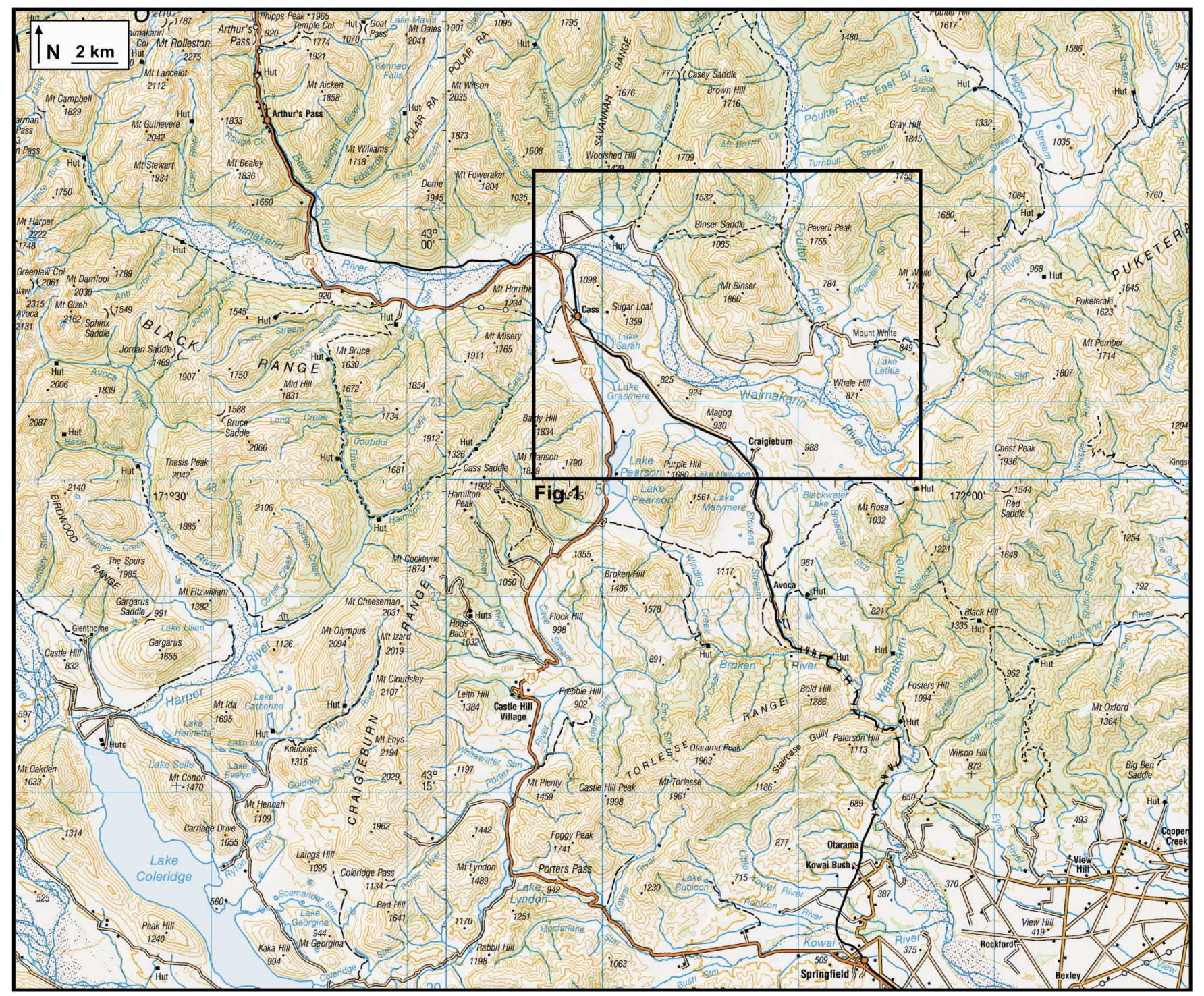

Middle Waimakariri River catchment and its surroundings as shown on the NZ250 Topo maps. The area covered by Figure 1 of the express report is indicated by the black frame. S 2 constitutes a composite of parts from 4 different map sheets (NZTopo 250-17 Greymouth, 18 Murchison, 22 Timaru, 23 Christchurch). The original scale has been changed (modified after Land Information New Zealand, https://www.linz.govt.nz/land/maps/topographic-maps). 


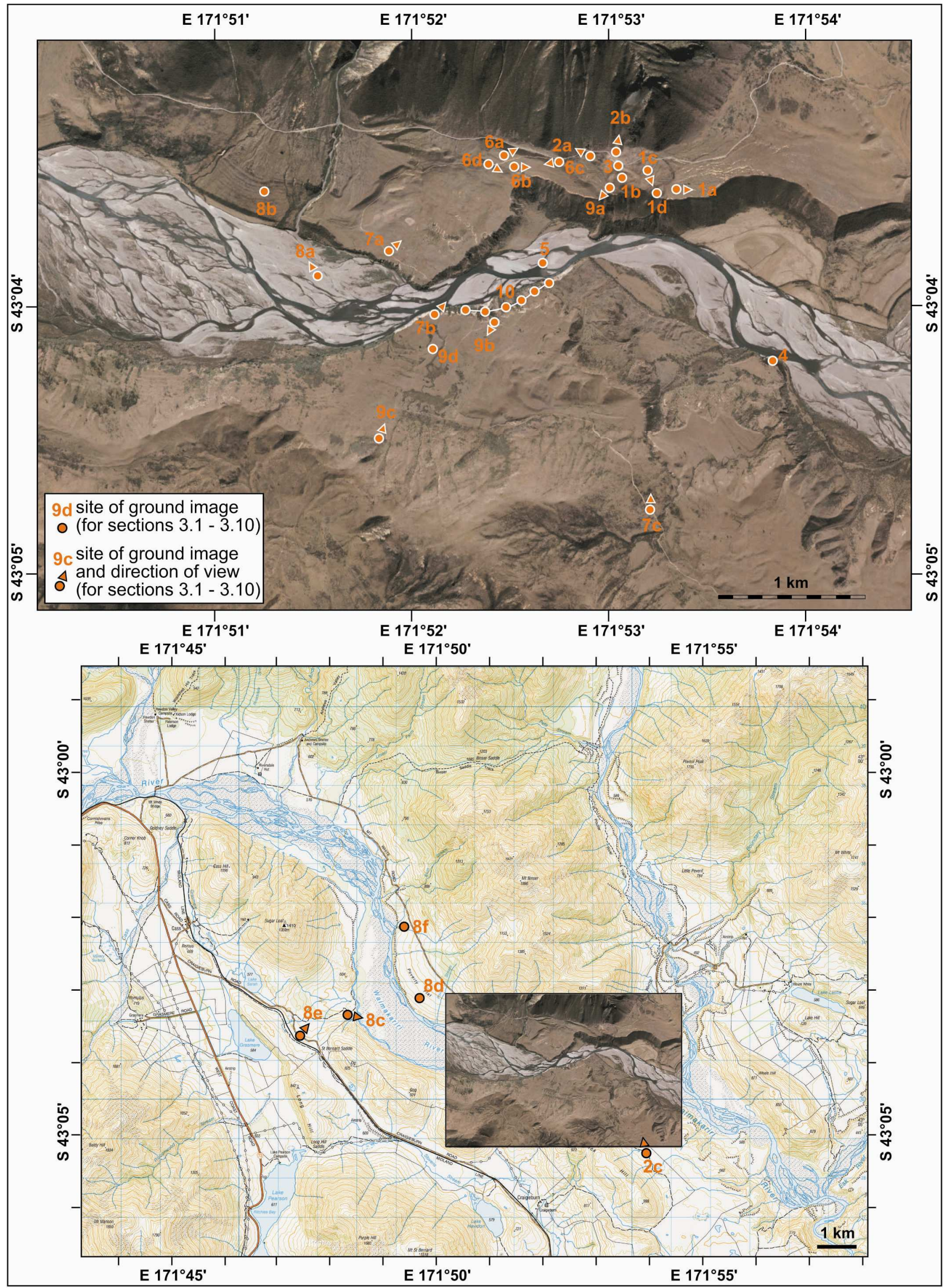




\section{S 3.0 (previous page):}

Figure providing spatial information on the sites of the ground images and, where appropriate, their direction of view presented in the following subsections of S 3. The areas displayed on the areal image/ topographic base map correspond to Figures 1 and 3 of the express report (modified after Land Information New Zealand, https://data.linz.govt.nz/data/category/aerial-photos, https://www.linz.govt.nz/land/ maps/topographic-maps).

S 3.1 Terminal moraine ('Poulter' moraine) at proposed damming site - northern valley side
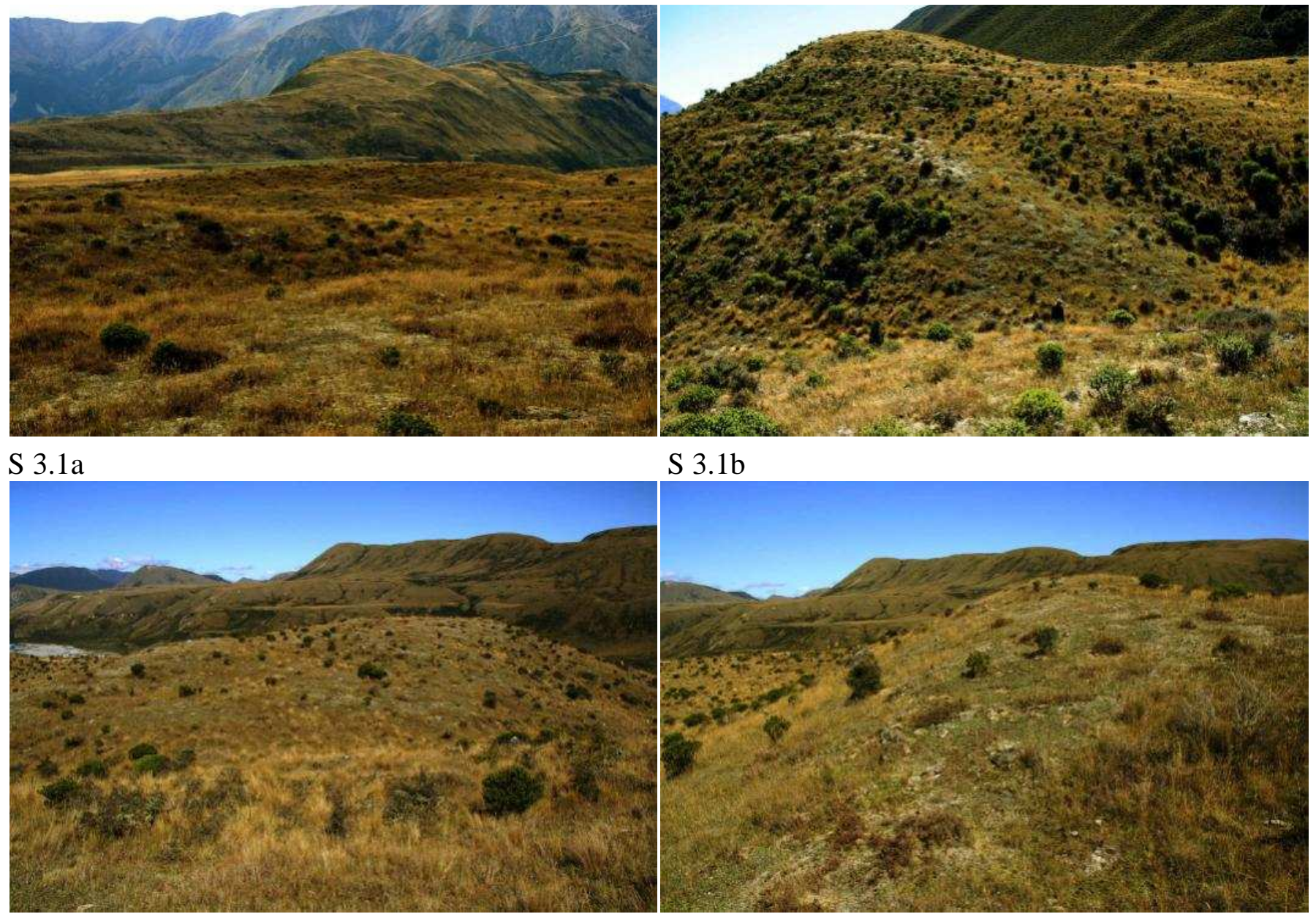

S 3.1c

S 3.1d

View of moraine ridges towards East (S 3.1a - Whale Hill in far background) and towards West (S 3.1b). Detailed views (S 3.1c and S 3.1d) are taken towards South-east. [(a) 01.03.2018, (b)-(d) 08.03.2018] 
S 3.2 Valley slope above proposed damming site - northern valley side
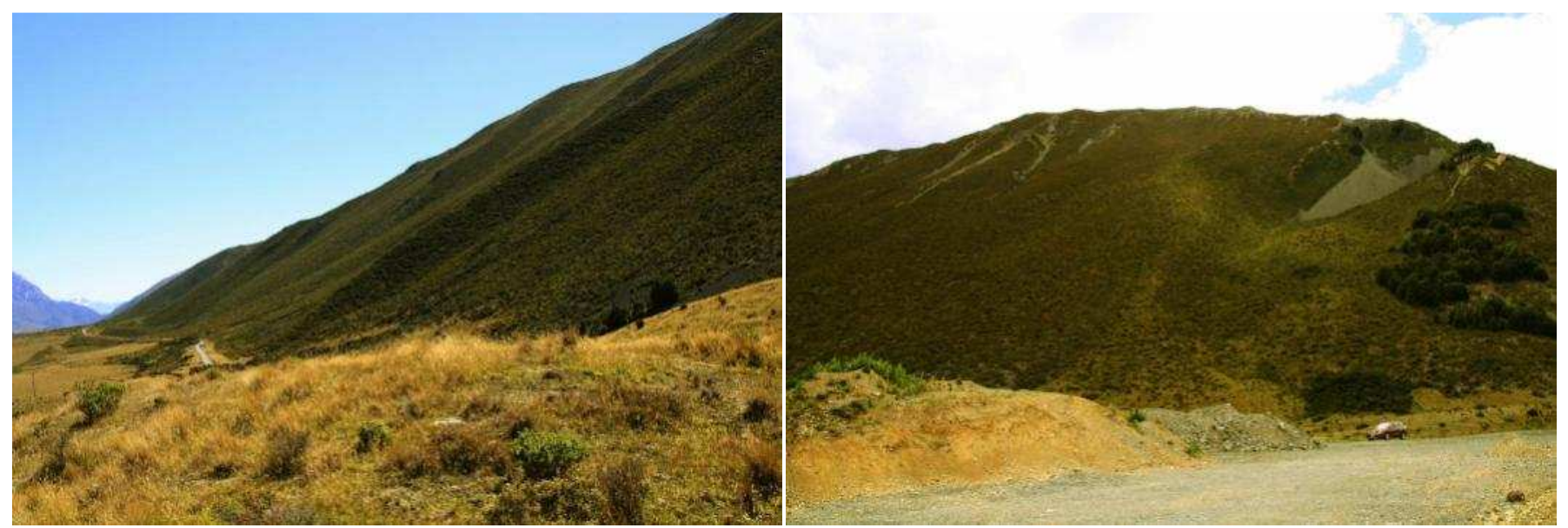

S $3.2 \mathrm{a}$

S $3.2 b$

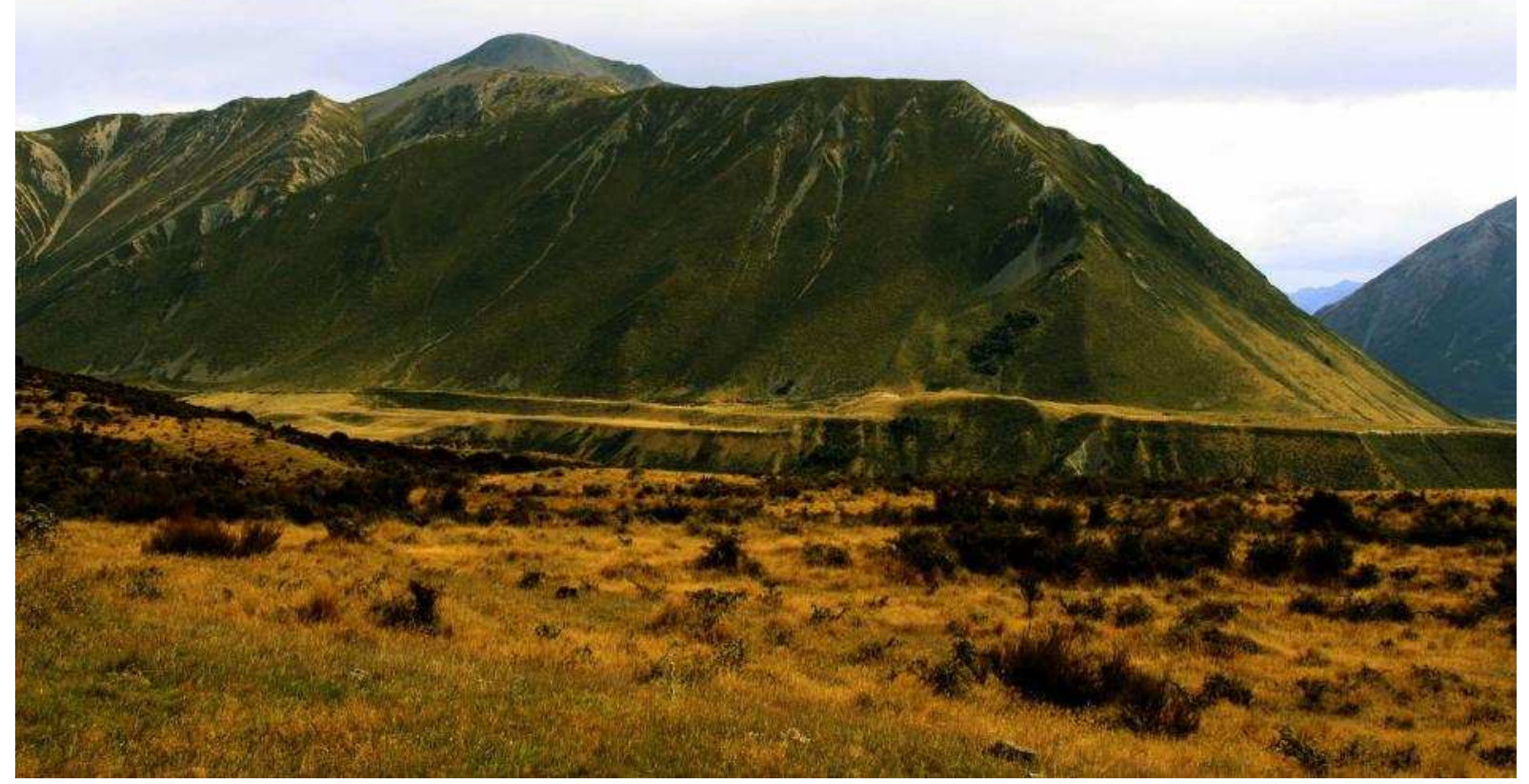

S 3.2c

View of valley slope above the proposed damming site from the innermost part of the terminal moraine ('Poulter' moraine; cf. S 3.1) towards the West (S 3.2a) and upslope in northerly direction (3.2b). On S $3.2 \mathrm{c}$, the complete damming site and valley slope is shown as seen from the South. Despite morphological traces of more recent slope processes and related sediment cover overlying a minor part of the terminal moraine at its base (cf. S 3.3) the lack of any obvious scarp on this slope points against it constituting the source area of a major landslide blocking Waimakariri River. Additionally, the preservation of both glaciofluvial terraces and major parts of the terminal moraine would be in conflict with any such hypothesis. [(a) 08.03.2018, (b) 30.11.2017, (c) 13.03.2018] 
S 3.3 Outcrop near surface of the innermost part of terminal moraine ('Poulter' moraine) at proposed damming site - northern valley side

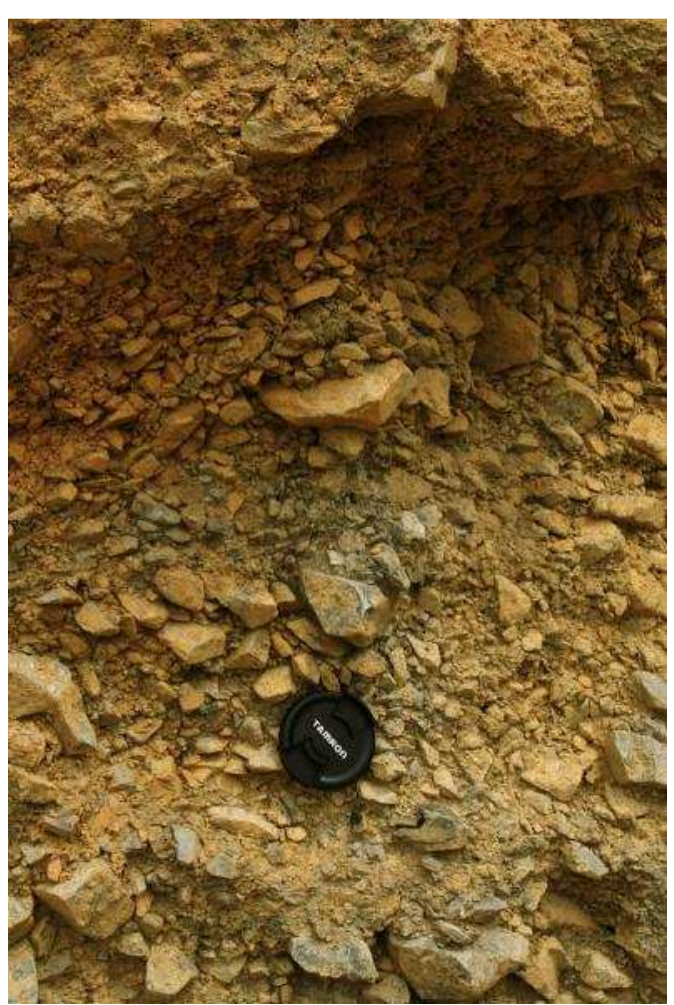

S 3.3a

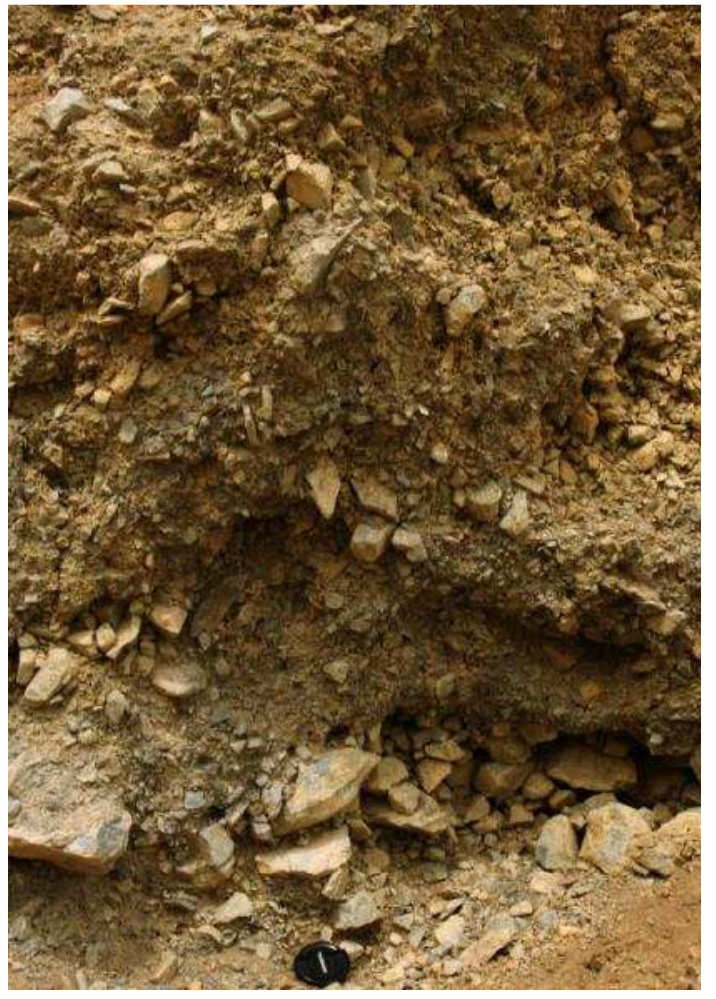

S $3.3 b$

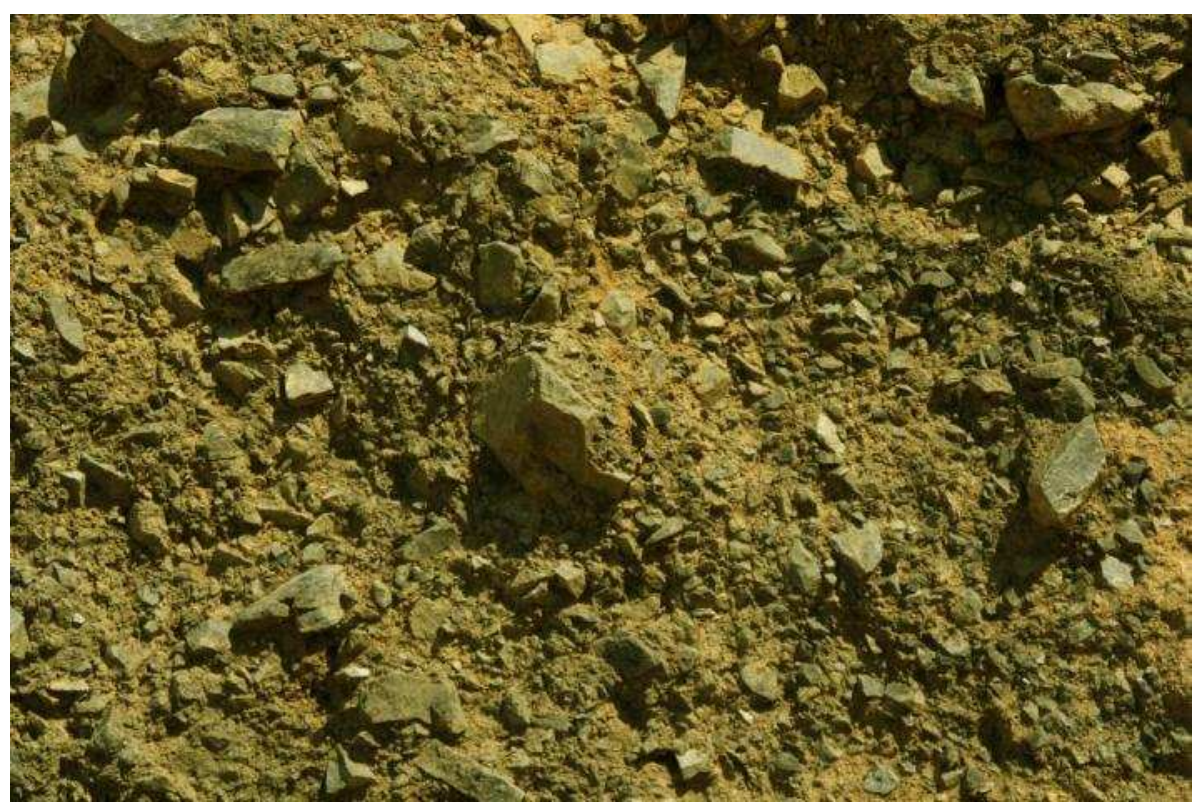

S $3.3 \mathrm{c}$

Details of outcrop section near the surface of the innermost part of the terminal moraine ('Poulter' moraine) at the proposed damming site (S 3.3a-c). The sediment of unknown total thickness (exposed maximum thickness $\sim 5 \mathrm{~m}$ ) superficially covers the terminal moraine and modifies its surface morphology, but is restricted to the innermost part of the moraine (cf. express report and its Figure 3b). It obviously originates from the nearby slope (see S 3.2), but no detailed process has been identified yet. Some tens of meters downvalley both moraine morphology and surface sediment appear as typical (see S 3.1). [(a)(b) 30.11.2017, (c) 01.02.2017] 
S 3.4 Bedrock outcrop downstream the proposed damming site on southern valley side.

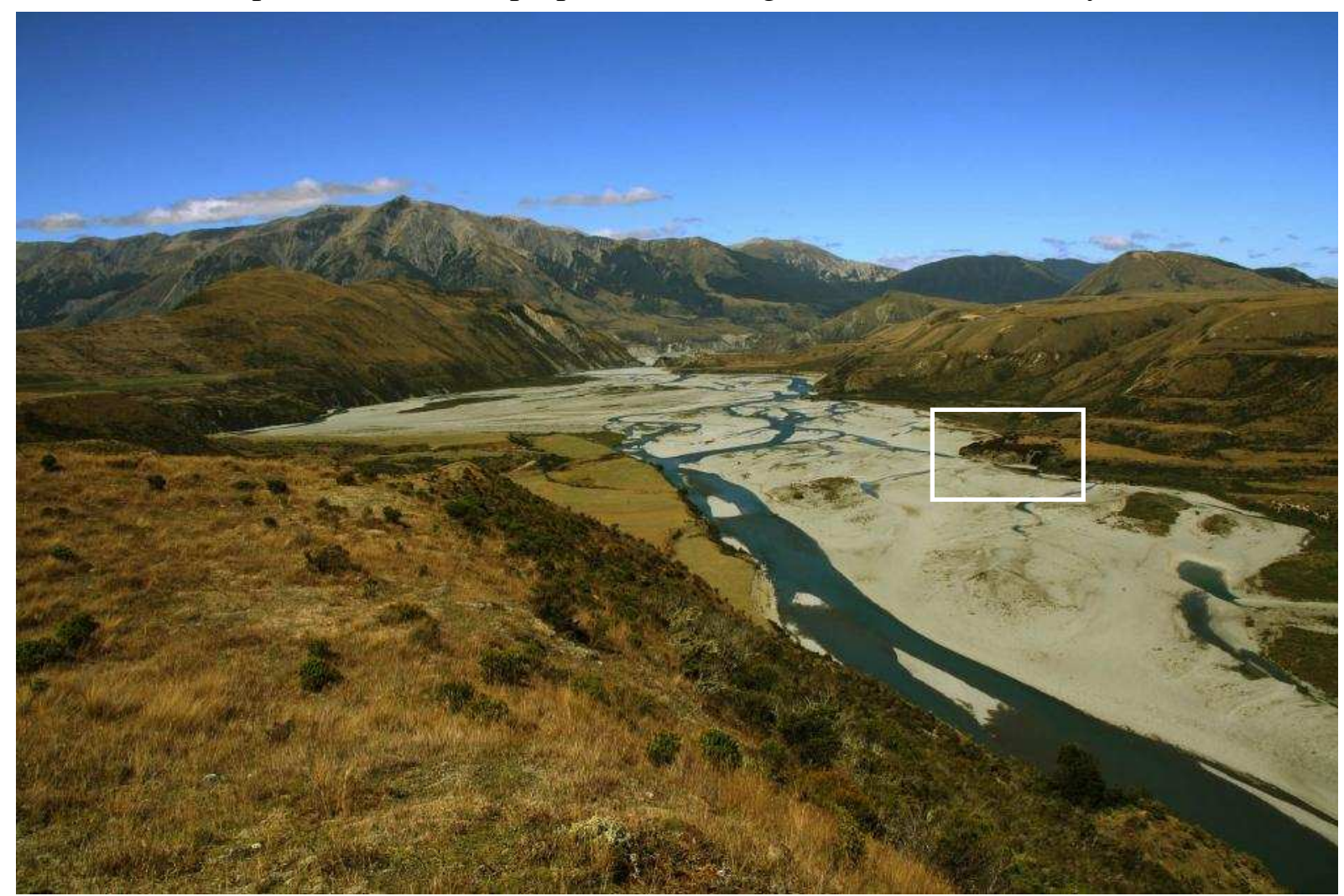

S 3.4a

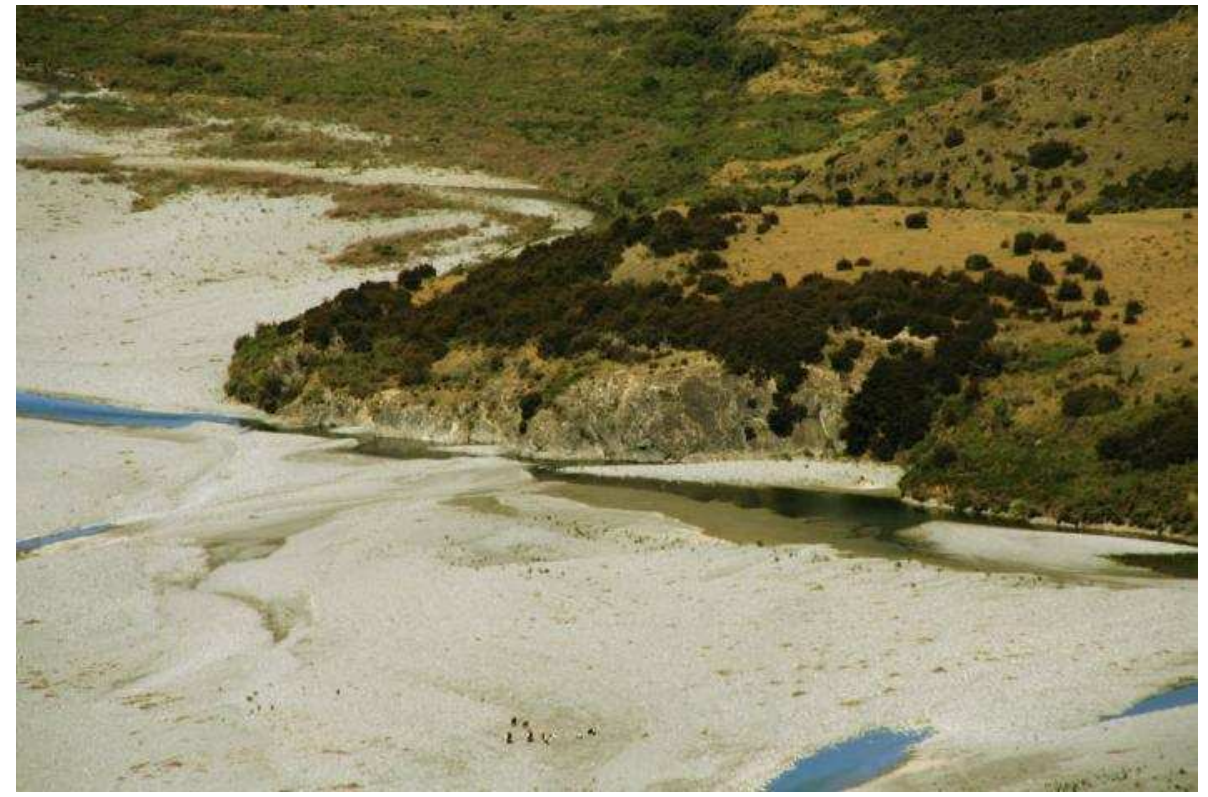

S $3.4 b$

Bedrock outcrop at Waimakariri River's active river channel downstream the proposed damming site immediately upstream the confluence of Poulter River (from left) as seen from the outer terminal moraine ('Poulter' moraine) in its general setting (S 3.4a) and in detail (S 3.4b). The bedrock (quartzofeldspatic Triassic sandstone and mudstone as part of the Torlesse composite terrane, regionally so-called 'greywacke' - Forsyth et al., 2008) has an elevation far too low (and is far too small in size) to constitute the remnant of any possible bedrock feature that could have dammed a temporary lake in the study area. Even the lowermost palaeolake shorelines and wave-cut benches upstream the proposed damming site are situated at much higher elevations above the active flood plain. [(a)(b) 08.03.2018] 
S 3.5 Huge boulder within Waimakariri River's active river channel at the proposed damming site.

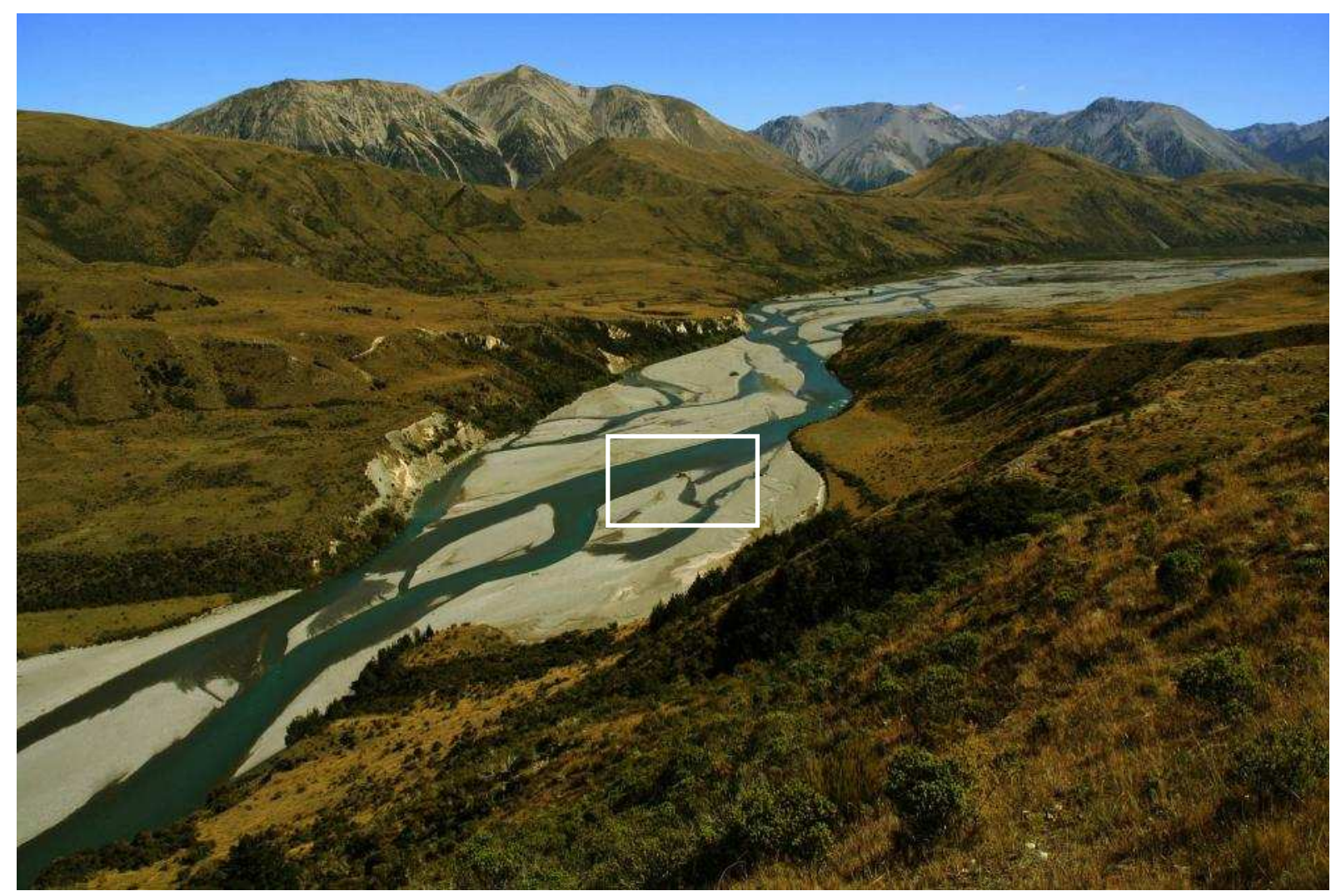

S $3.5 \mathrm{a}$

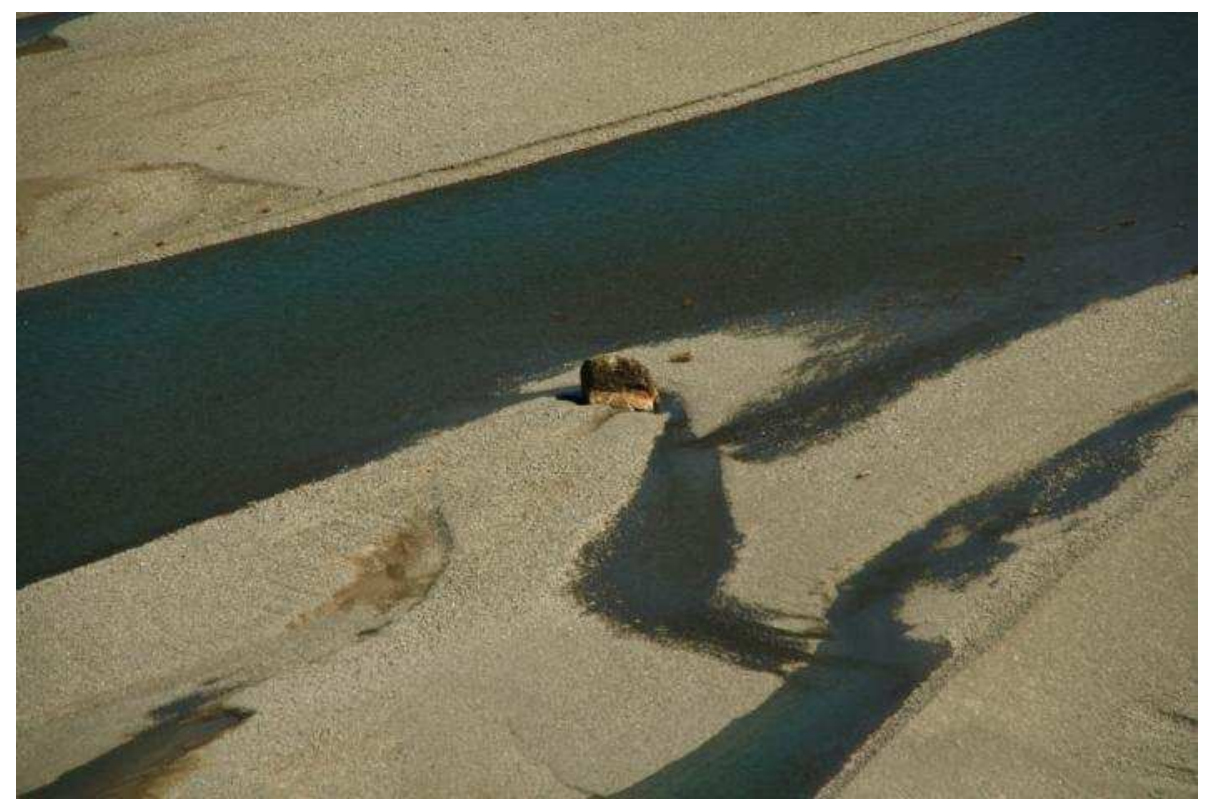

S $3.5 b$

Huge boulder within Waimakariri River's active river channel at the proposed damming site as seen from the outer terminal moraine ('Poulter' moraine) in its general setting (S 3.5a) and in detail (S 3.5b). The boulder may constitute the remnant of a former slump that once blocked the river at this site (see express report for more details on this hypothesis), but other origins cannot be excluded. Therefore, it remains inconclusive. [(a)(b) 08.03.2018] 
S 3.6 Terraces/Terrace scarps proximal to the terminal moraine ('Poulter' moraine) at proposed damming site - northern valley side
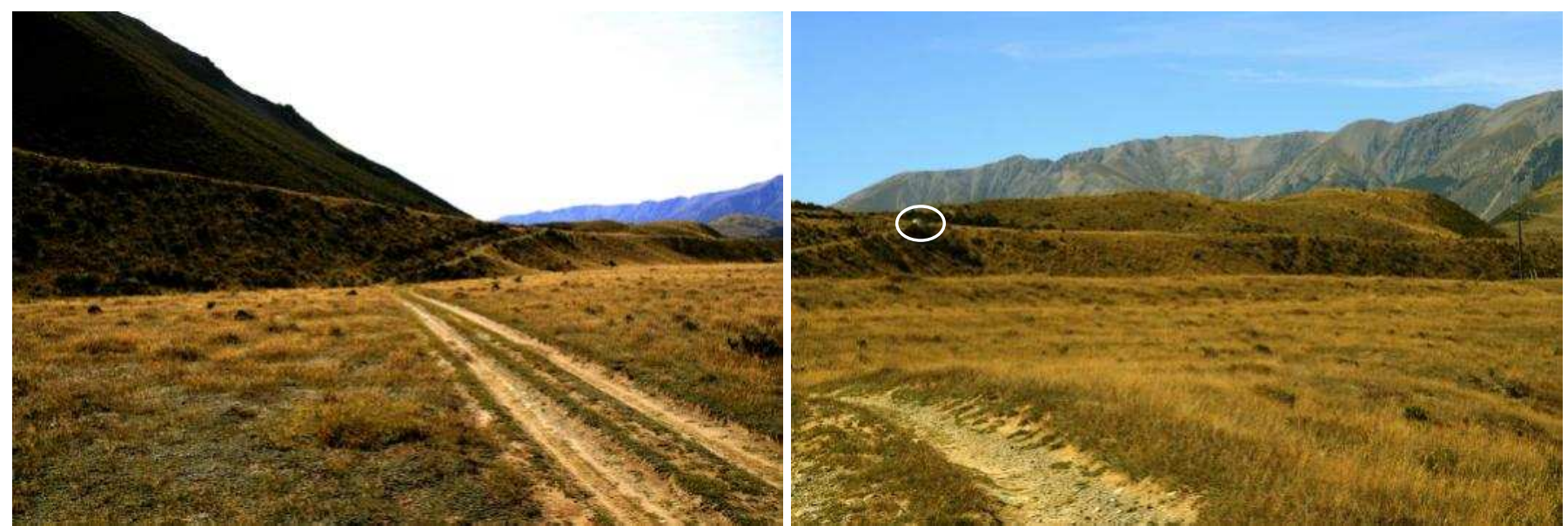

S 3.6a

S $3.6 b$

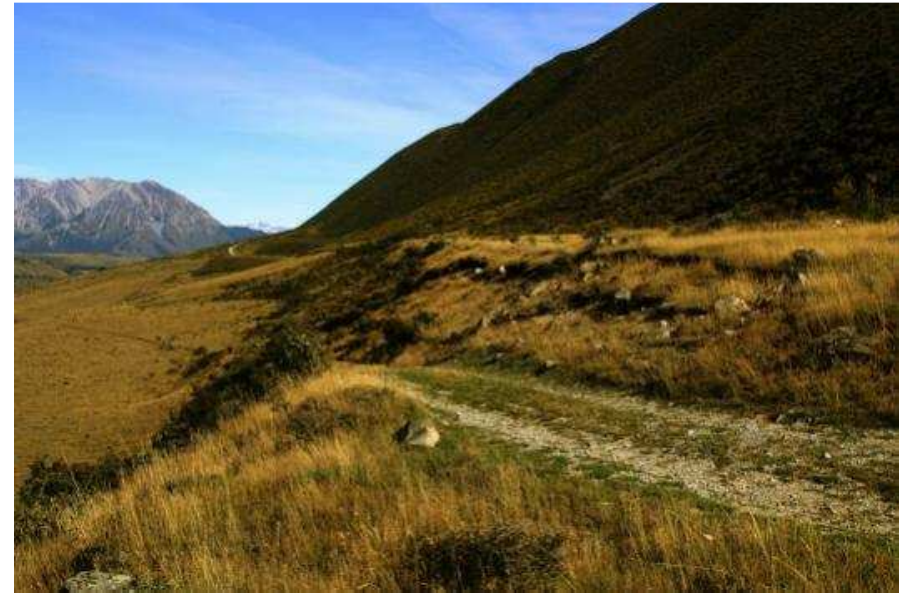

S $3.6 \mathrm{c}$

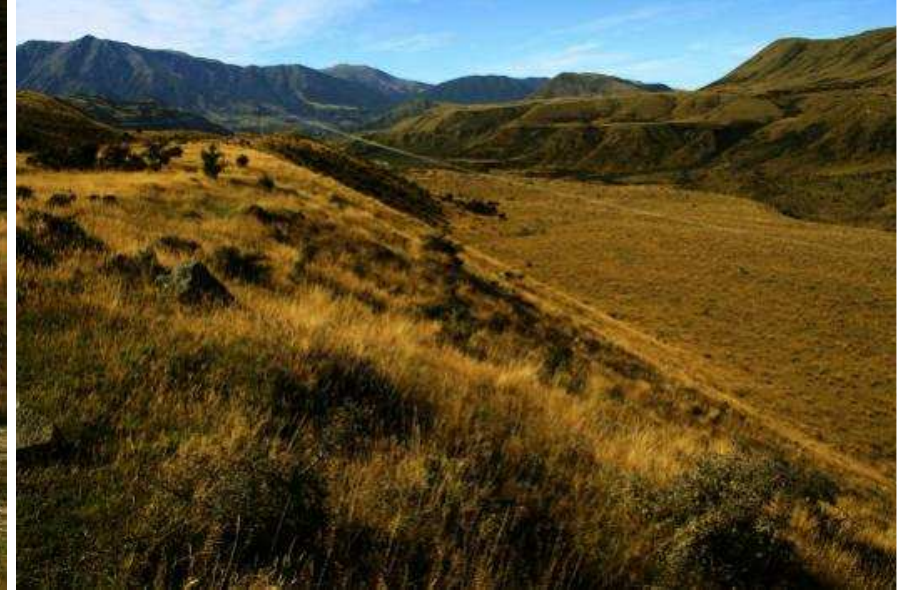

S $3.6 \mathrm{~d}$

Terraces and prominent terrace scarps proximal to the terminal moraine ('Poulter' moraine) at the proposed damming site. The upper terrace has been formed directly at the slope's base. Its elevation is substantially higher $(70+\mathrm{m})$ than the nearest uppermost wave-cut bench representing the maximum former lake level. It shows erosion at the proximal ridge of the terminal moraine system and must have developed immediately after the ice margin retreated. High elevation (and related base level) exclude any younger age and the straight outline of the terrace scarp can only be explained by an established meltwater channel cut through the terminal moraine at that time. Furthermore, it indicates substantial incision and base level lowering at some successive stage. The upper terrace surfaces are parallel and can easily be traced from a distance (cf. S 3.7c). S 3.6a shows the prominent terrace scarp close to the slope base, S $3.6 \mathrm{~b}$ additionally the proximity to the terminal moraine (background, both images seen towards the East; circle indicates car for scale). The view from the upper terrace down the scarp towards the West (S. 3.6c) shows how the upper terrace is directly in contact with the slope's base; the view towards the East ( $\mathrm{S}$ 3.6d) how the wide lower terrace itself is bound by a prominent scarp, the latter possibly related to a hypothetical slump that is proposed as an alternative process responsible for blocking Waimakariri River and damming the palaeolake (cf. S 3.7; see express report for more details). [(a)-(d) 12.03.2018] 
S 3.7 Features at the proposed damming site - northern valley side

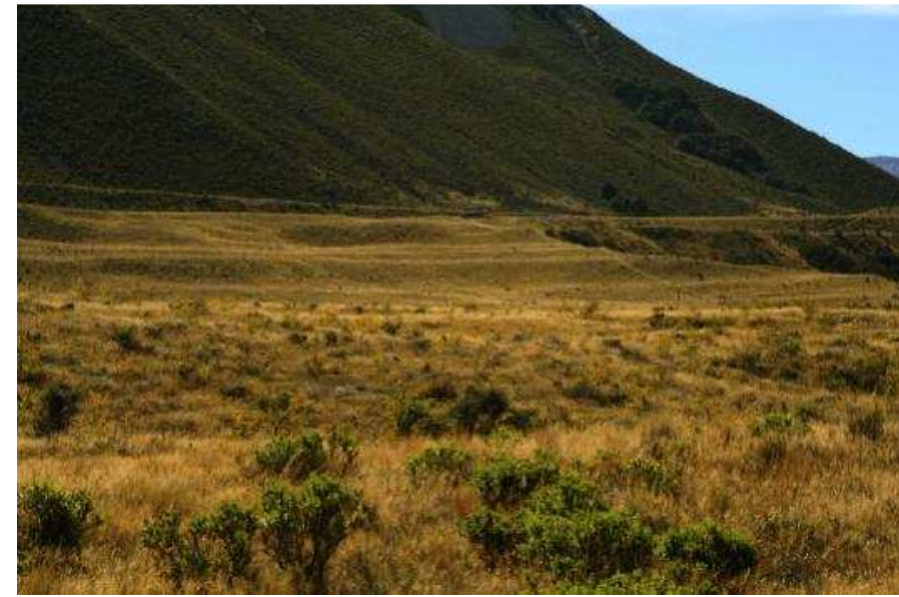

S $3.7 \mathrm{a}$

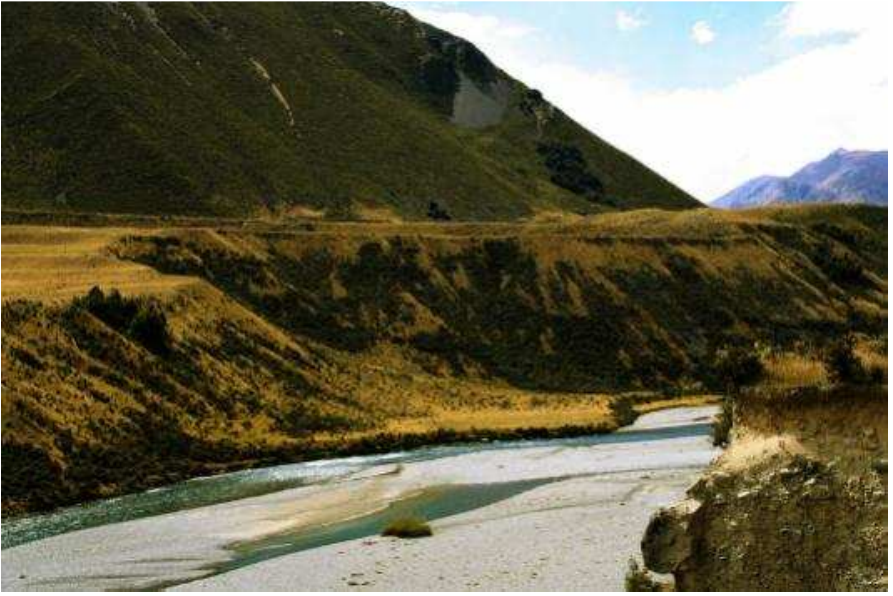

S $3.7 b$

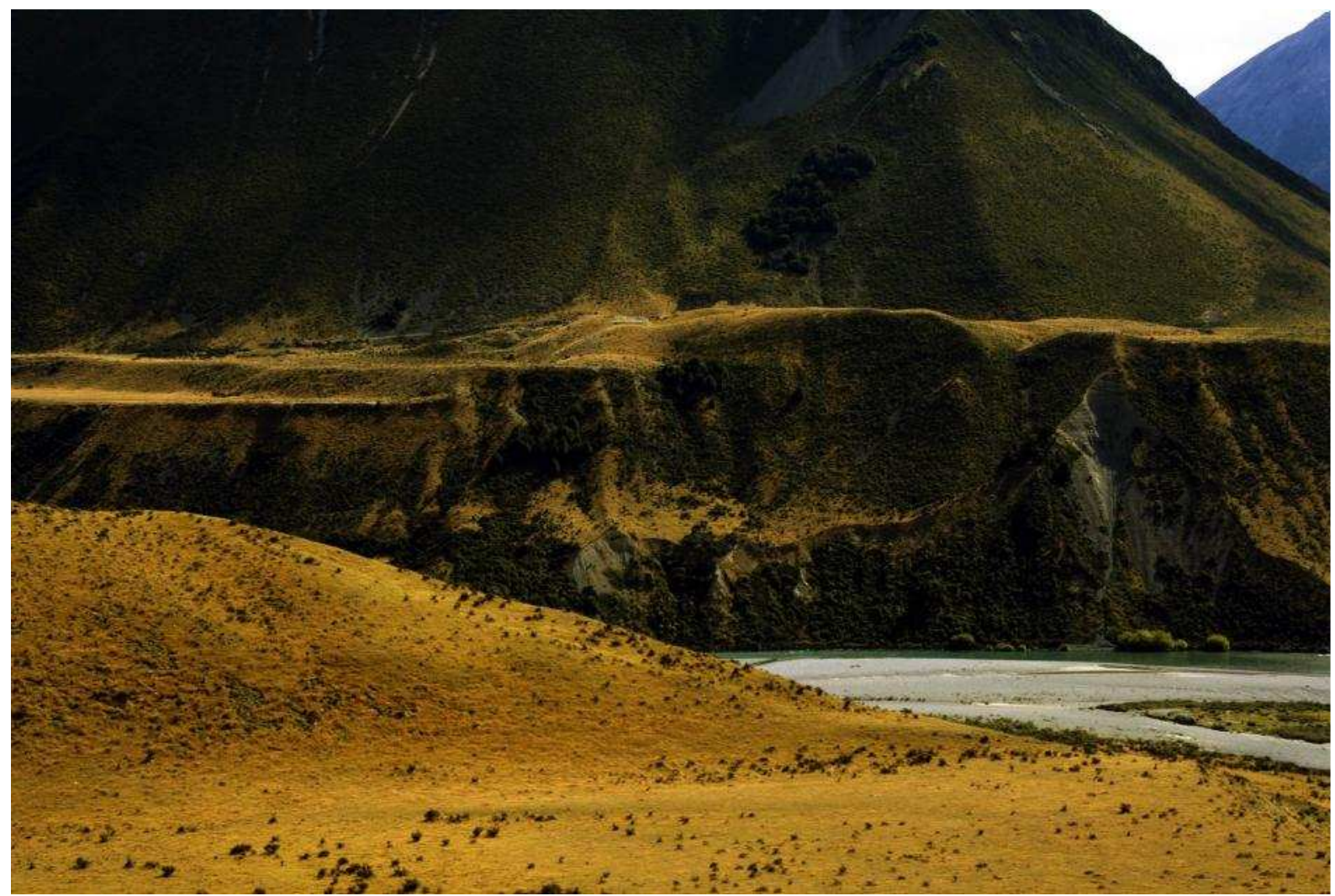

S 3.7c

Features at the proposed damming site. The two upper terraces and their prominent terrace scarps (see $\mathrm{S}$ 3.6) are visible even from a distance on all three images. The (younger) terraces visible in the foreground seen from the scarp of the active river flood plain on the same side of the valley (S 3.7a) are cut at the far right by a massive scarp depicted on $\mathrm{S} 3.7 \mathrm{~b}$ (left part). S 3.7b has been taken from the opposite valley side. S $3.7 \mathrm{c}$ is taken from a further distance and illustrates how this massive scarp exceeding $100 \mathrm{~m}$ has eroded into both terminal moraine system ('Poulter' moraine') on the right and proximal terraces on the left. This massive scarp may potentially be linked to a possible slump that blocked Waimakariri River (for more details see express report and, in particular, its Figure 3 ). [(a) 12.03.2018, (b)(c) 13.03.2018] 
S 3.8 Wave-cut benches as evidence of a former temporary lake

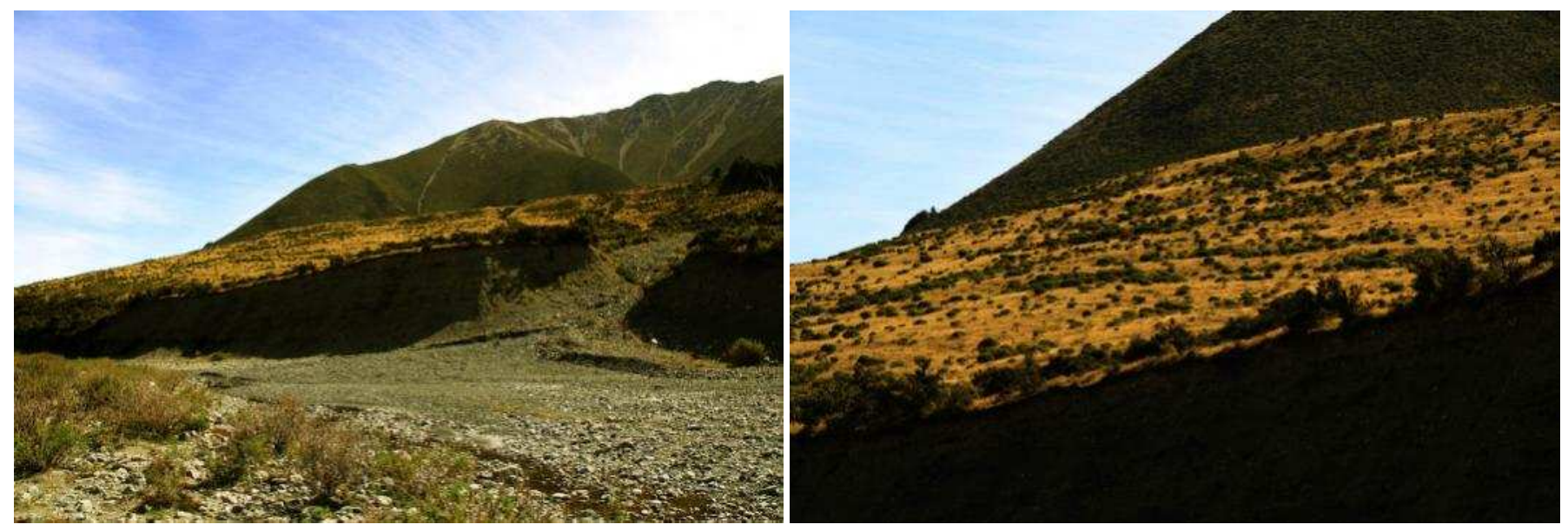

S 3.8a

$\mathrm{S} 3.8 \mathrm{~b}$
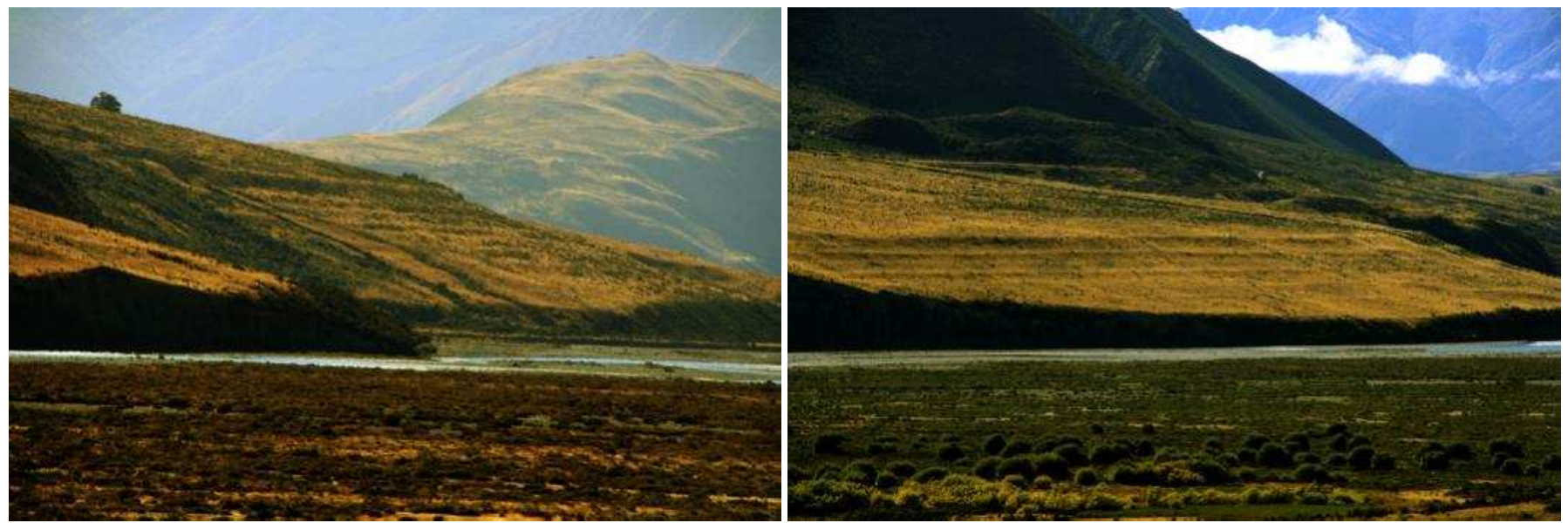

S $3.8 \mathrm{c}$

S 3.8d
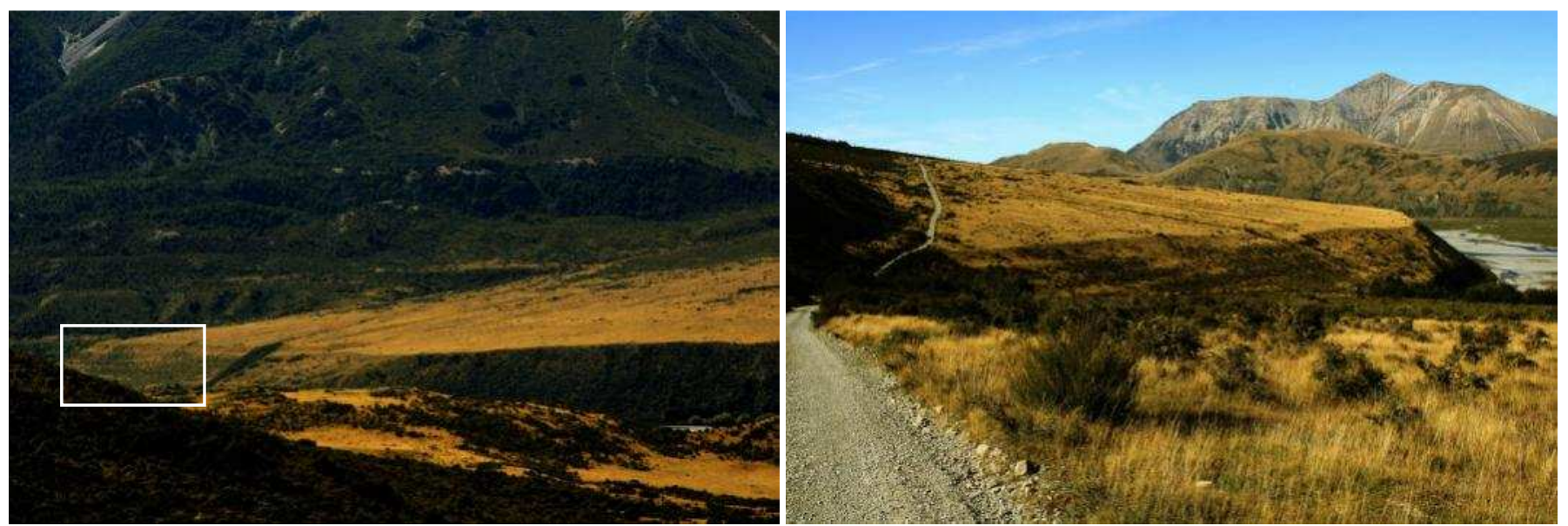

S $3.8 \mathrm{e}$

S $3.8 \mathrm{f}$

Wave-cut benches linked to the former temporary lake formed on fans in the study area. S 3.8a (S 3.8b detail) shows benches developed on the fan closest to the proposed damming site (Gooseberry Stream currently incising its own fan). S 3.8c depicts the same benches from a position further upstream, S 3.8d shows benches on the lower central Binser fan. At the northernmost part of Binser Fan (S 3.8e), fewer benches that are less developed occur ( $\mathrm{S} \mathrm{3.8f}$ - location indicated on S 3.8e by frame). On both S 3.8d and $\mathrm{S} 3.8 \mathrm{e}$ it can be seen how Binser Fan marginally covers glacial/glaciofluvial features (see express report). [(a)(b)(f) 12.03.2018, (c) 16.02.2017, (d) 10.02.2018, (e) 08.03.2018] 
S 3.9 Palaeolake shorelines as evidence of a former temporary lake - southern valley side
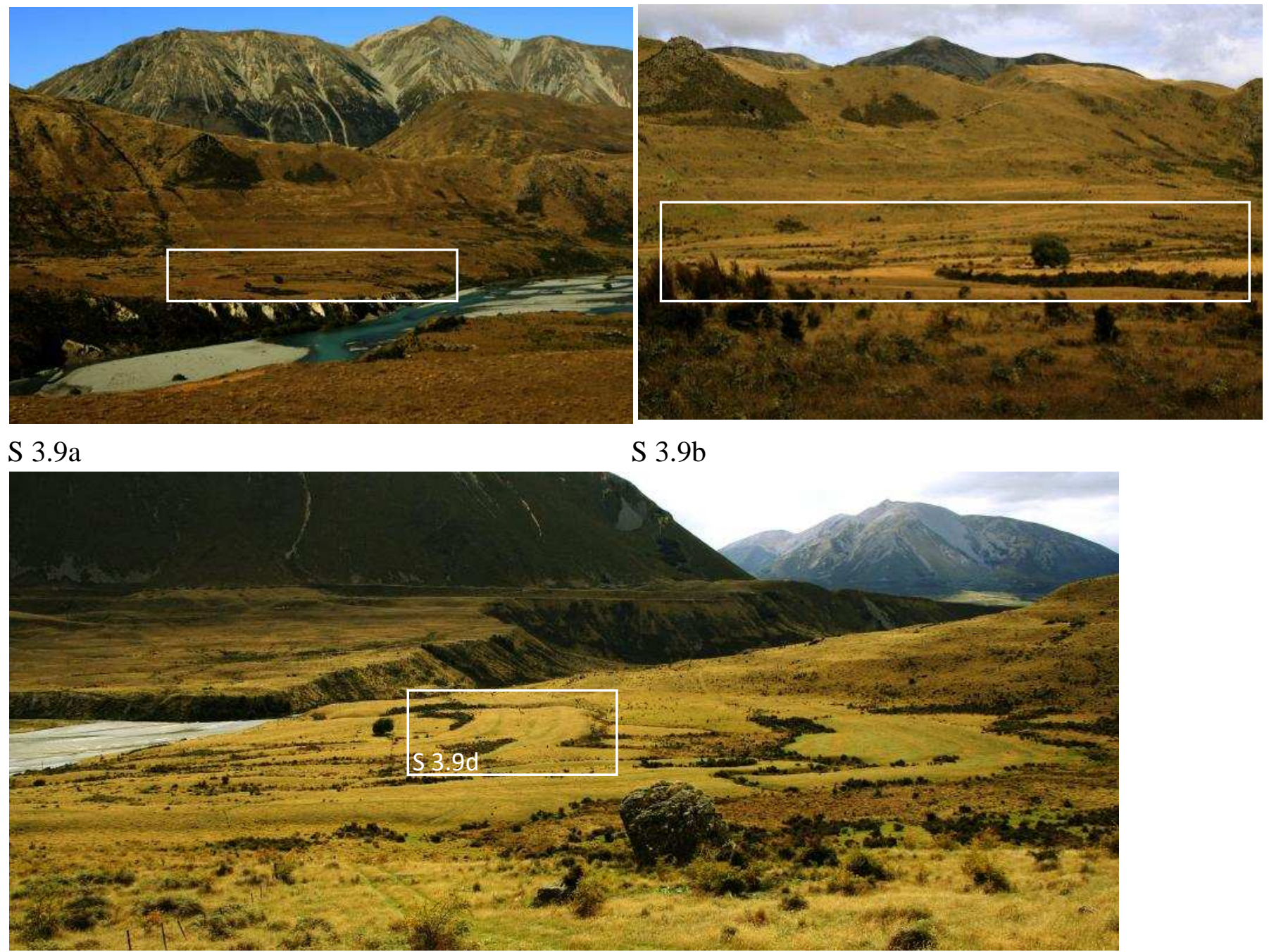

S $3.9 \mathrm{c}$

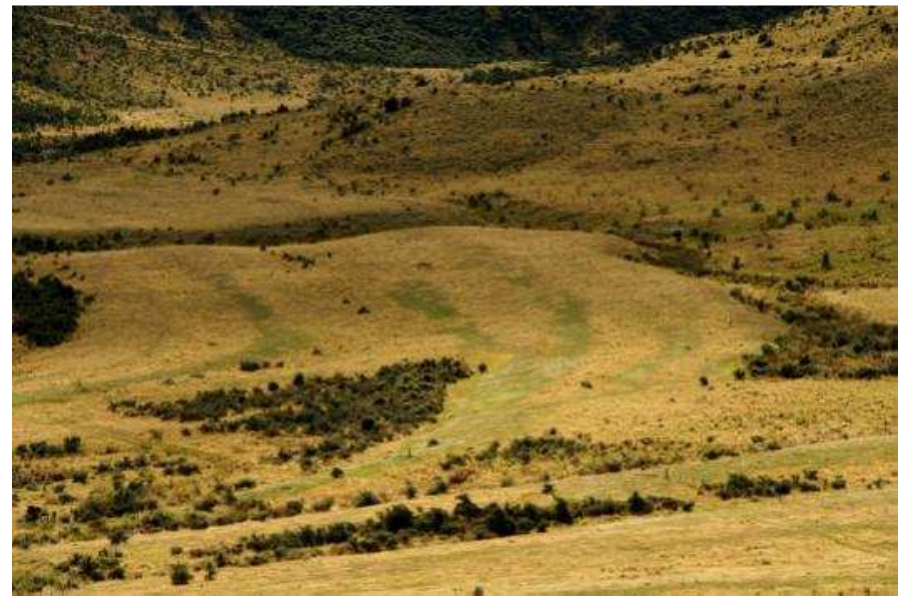

\section{S 3.9d}

Palaeolake shorelines in a flat area on the southern valley site close the proposed damming site (cf. express report, Figure 3). Their detailed location is indicated by frames on both S 3.9a and S 3.9b. They also show their location well below lateral moraines and (glacio)fluvial terraces that are preserved in this part of the valley. S 3.9c depicts the main area and illustrates that multiple shorelines occur, whereas $\mathrm{S}$ 3.9d provides a detailed view of the low ridges. [(a) 15.02.2017, (b)-(d) 13.03.2018]. 
S 3.10 Glacial and glaciofluvial sediments exposed at the scarps of the active river channel
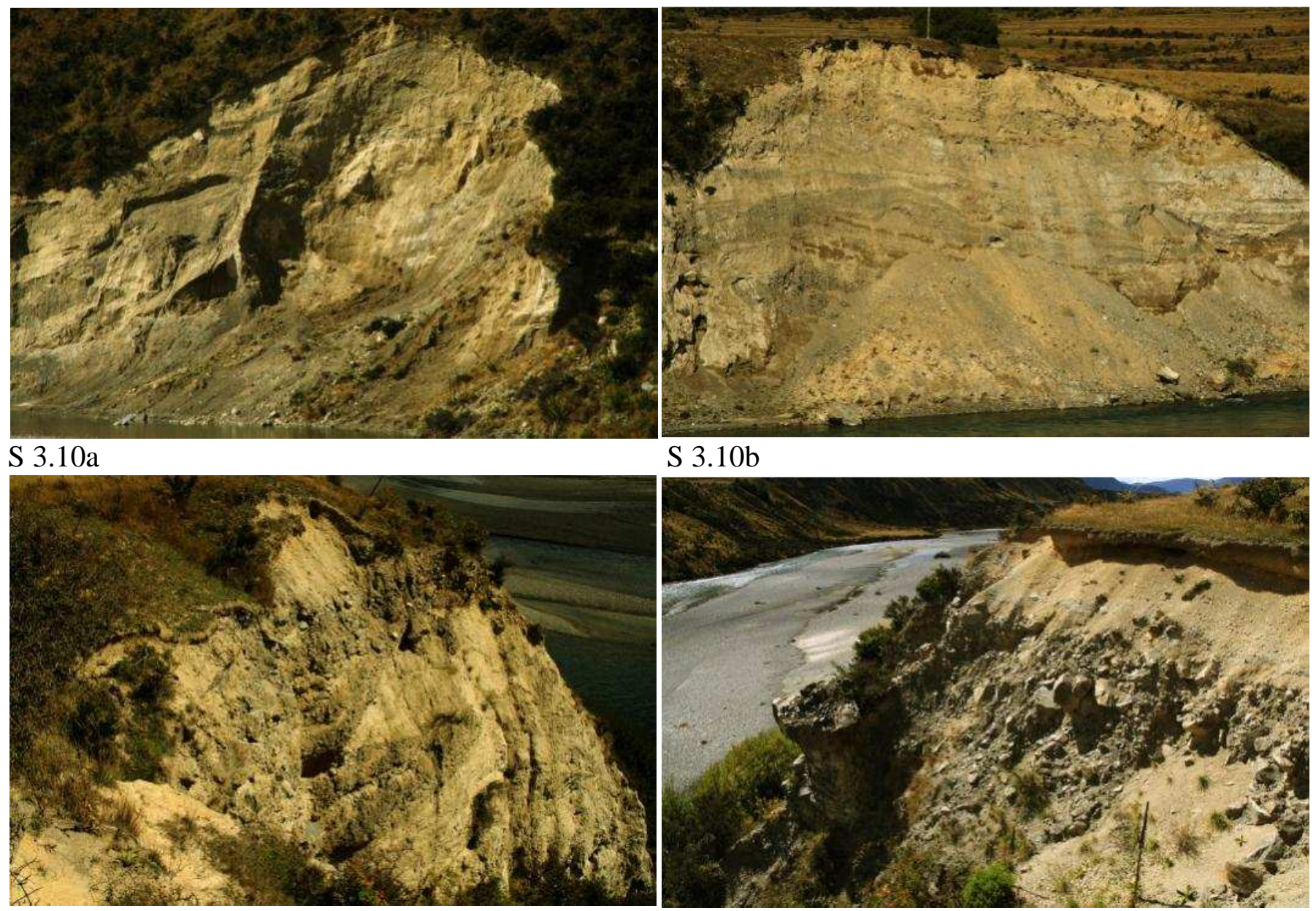

S 3.10c

S 3.10d
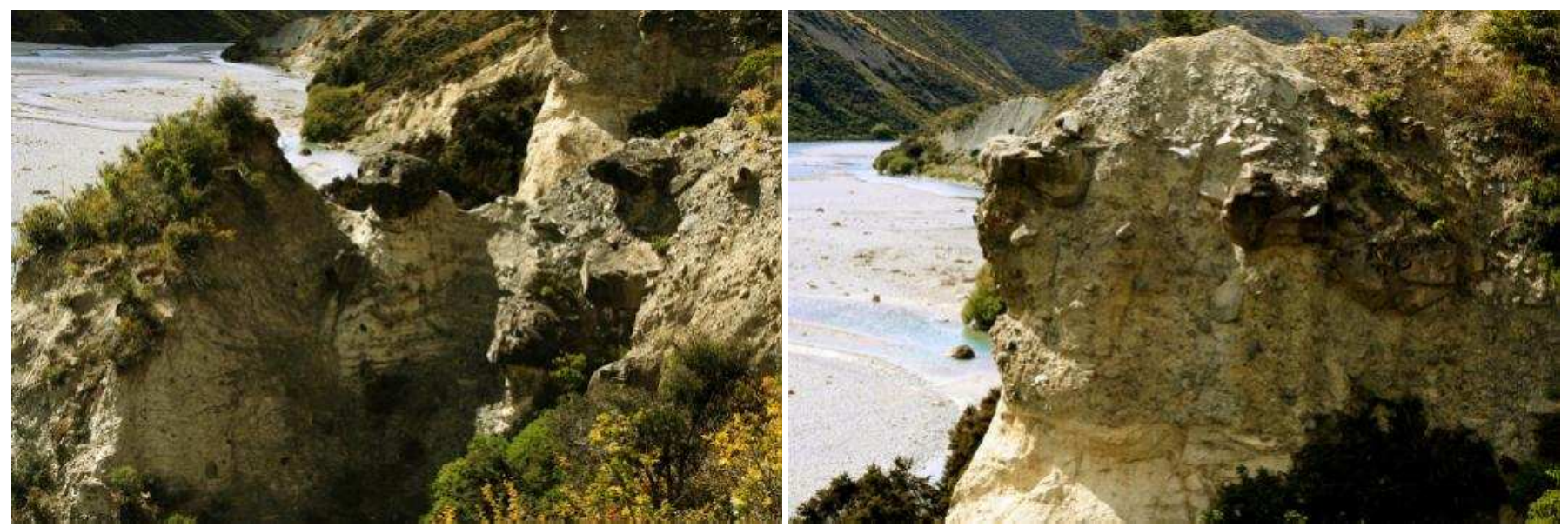

S 3.10e

S $3.10 f$

Glacial and glaciofluvial sediments exposed at the scarps of the active river channel at and immediately upstream the proposed damming site. All images are taken on the southern valley side and the sediments shown are not influenced by the massive fans that dominate the opposite valley side. The sedimentology is very complex and will be explored further during the ongoing study. At this stage, no indication for a massive landslide originating from the slopes above has been detected (cf. S 3.2 and express report). Some silty layers (e.g. visible on S 3.10e,f) appear as of glaciolimnic origin, but their stratigraphic position excludes any connection to the temporary lake because they must be older. They correspond to proglacial lake sediments Gage (1958) mentions as having deposited during the retreat to the 'Poulter' moraine positions and are of pre-'Poulter' advance age [(a)(b) 12.03.2018, (c)-(f) 13.03.2018]. 


\section{S 4 Oblique aerial images (06.01.2013)}

Sections of Waimakariri River from Hawdon River downstream to the Esk River confluence.

The oblique aerial images presented below have been taken from a flight path west of the study area heading from the Northwest towards the Southeast a few thousand metres above the ground. The direction of view is, consequently, always towards the Northeast (please see also Figure 1 of the express report and S 2). The individual images virtually follow the course of the Waimakariri River from the Hawdon to the Esk River confluences. They nicely display the setting of the middle Waimakariri River Valley within a landscape characteristic for the Southern Alps of New Zealand. Apart from the active floodplains and palaeochannels of the braided rivers like Waimakariri River and its main tributaries visible on all images, the huge fans abundant in the region are obvious features, in particular Binser Fan (see S 4b,c,d). On S 4a and 4b parts of the Cass basin west to the Waimakariri River can be seen. During the last Glaciation including the 'Poulter advance' a branch of the glacier occupying Waimakariri River Valley entered the Cass Basin through the saddle visible on S 4a (cf. Barrell et al. 2011; Rother et al. 2015). Only the upper section of Waimakariri Gorge is displayed on S 4f. As highlighted in the text of the express report, it would theoretically be relatively easy to dam Waimakariri River by a landslide at any location within this gorge. But because there is no morphological or sedimentological evidence of 'Lake Speight' extending downstream the Poulter River confluence (see S 4e,4f), this alternative hypothesis is not realistic and has to be rejected (see express report for more details).

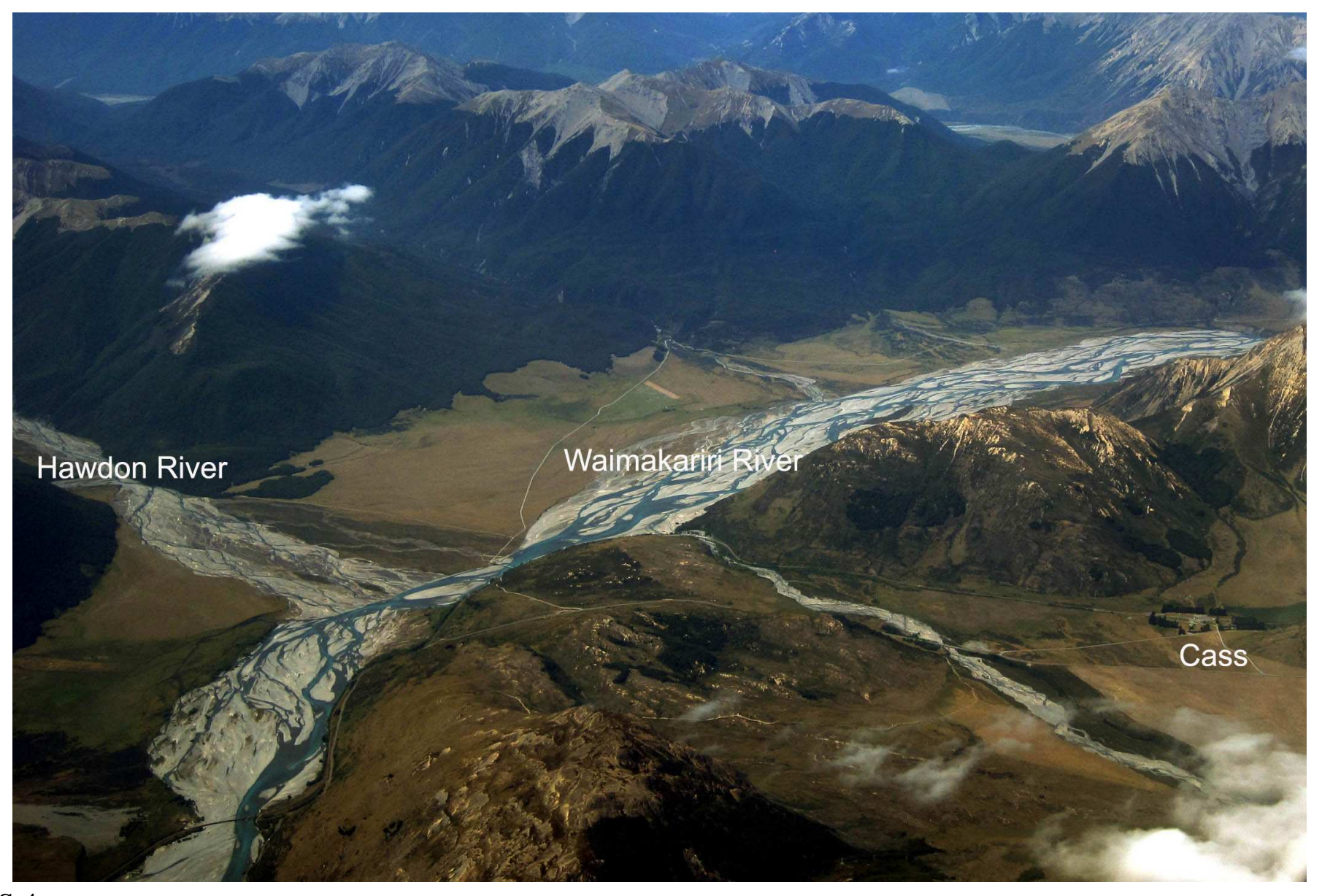

S $4 \mathrm{a}$ 


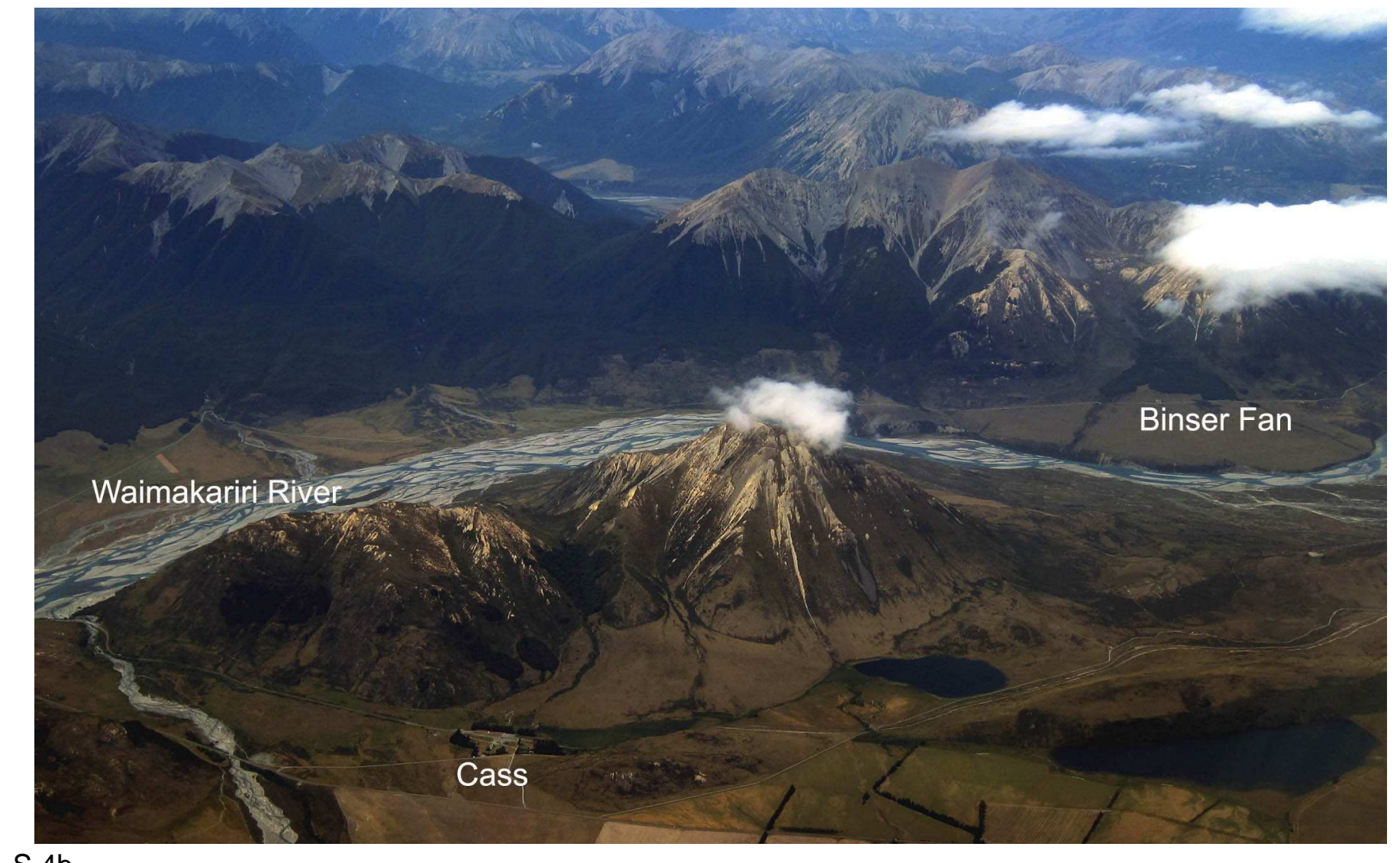

$S 4 b$

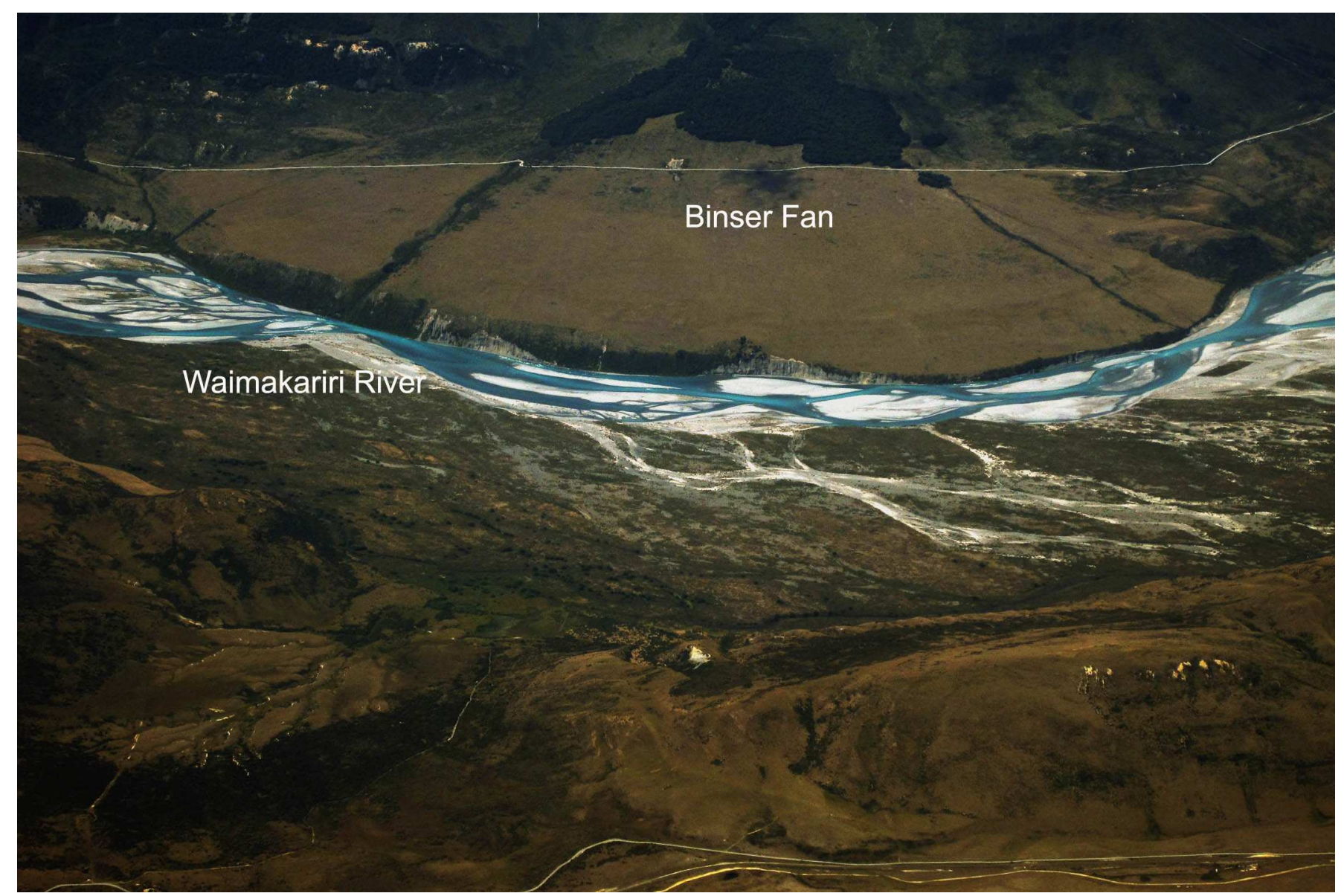

$S 4 c$ 


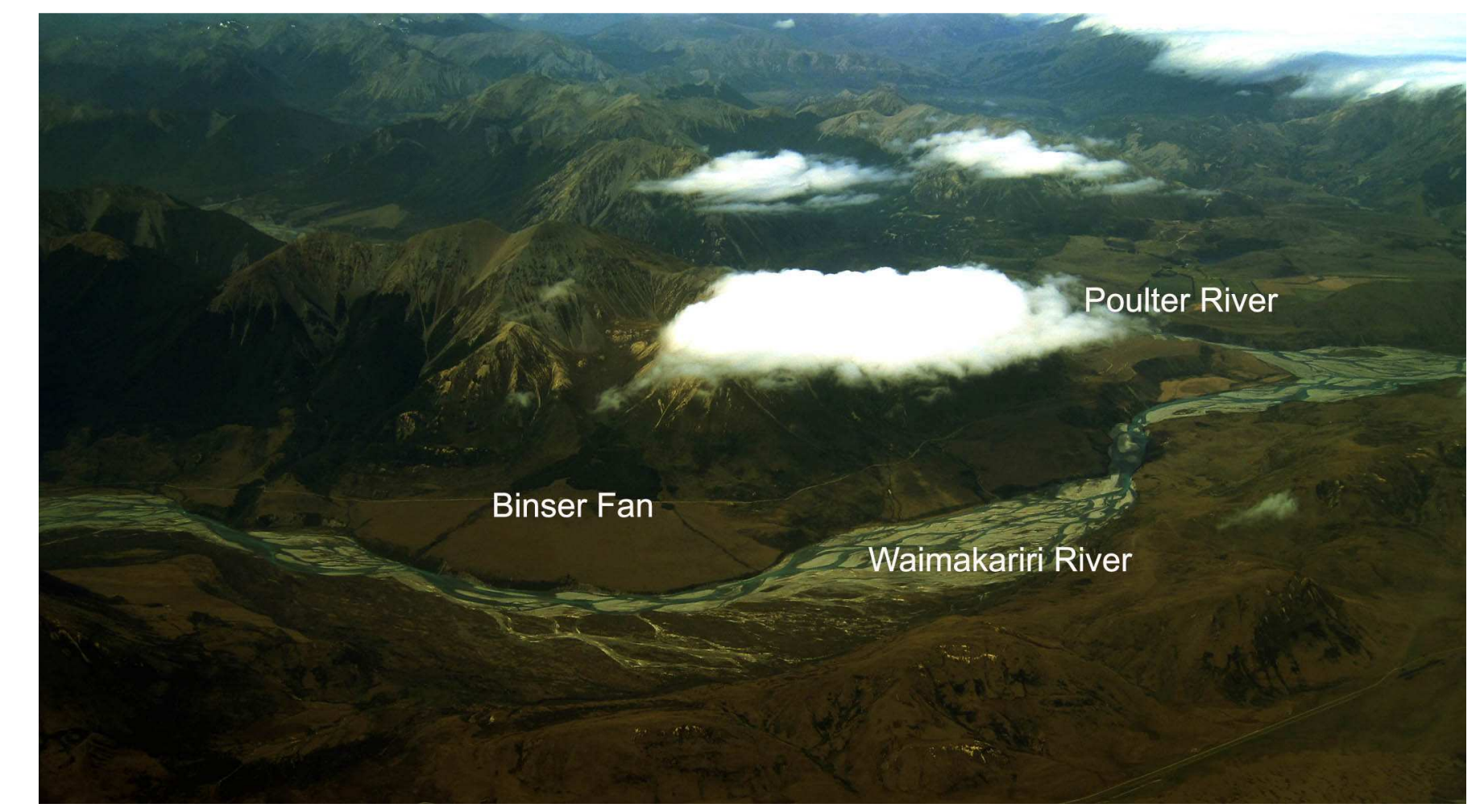

$S 4 d$

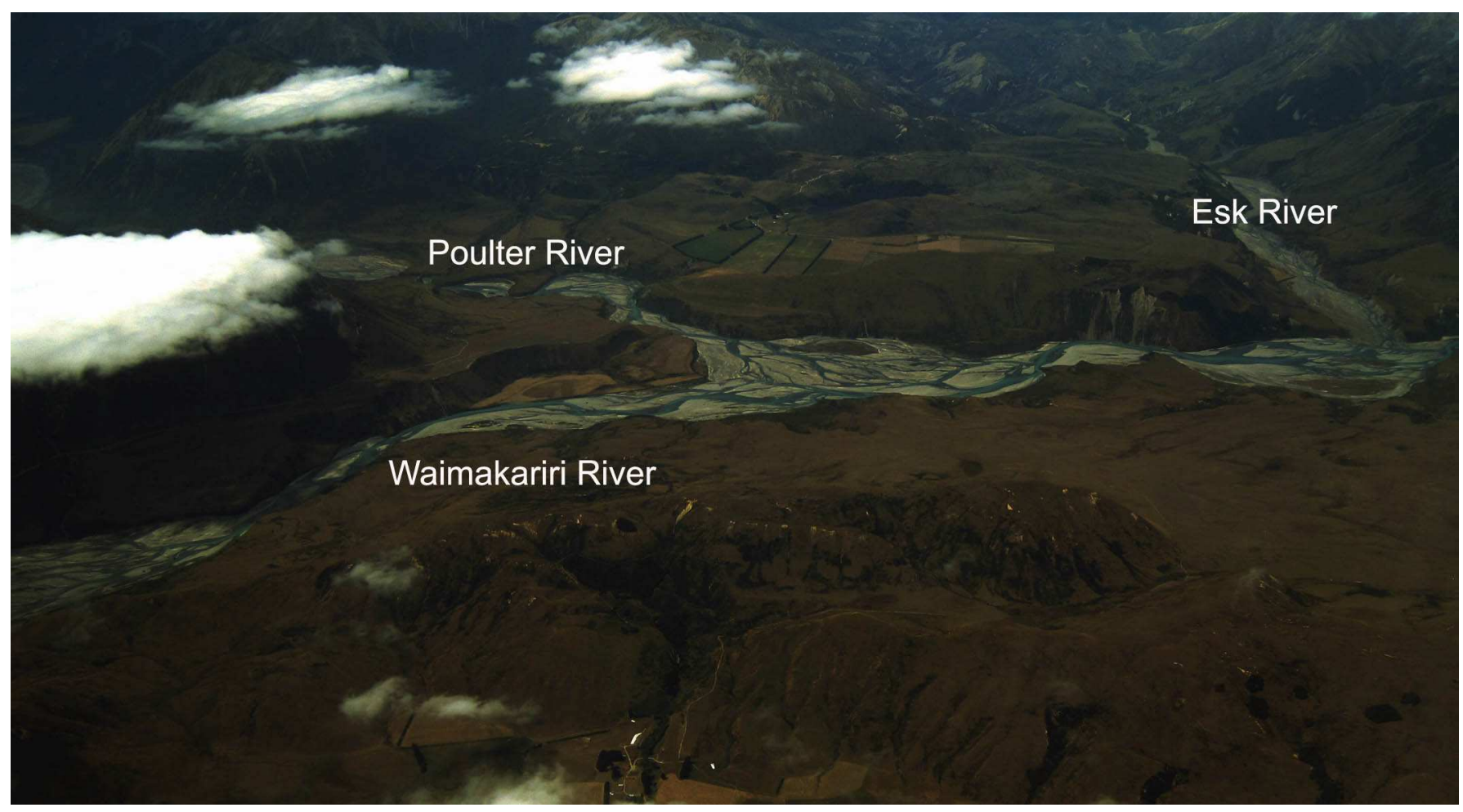

$\mathrm{S} 4 \mathrm{e}$ 


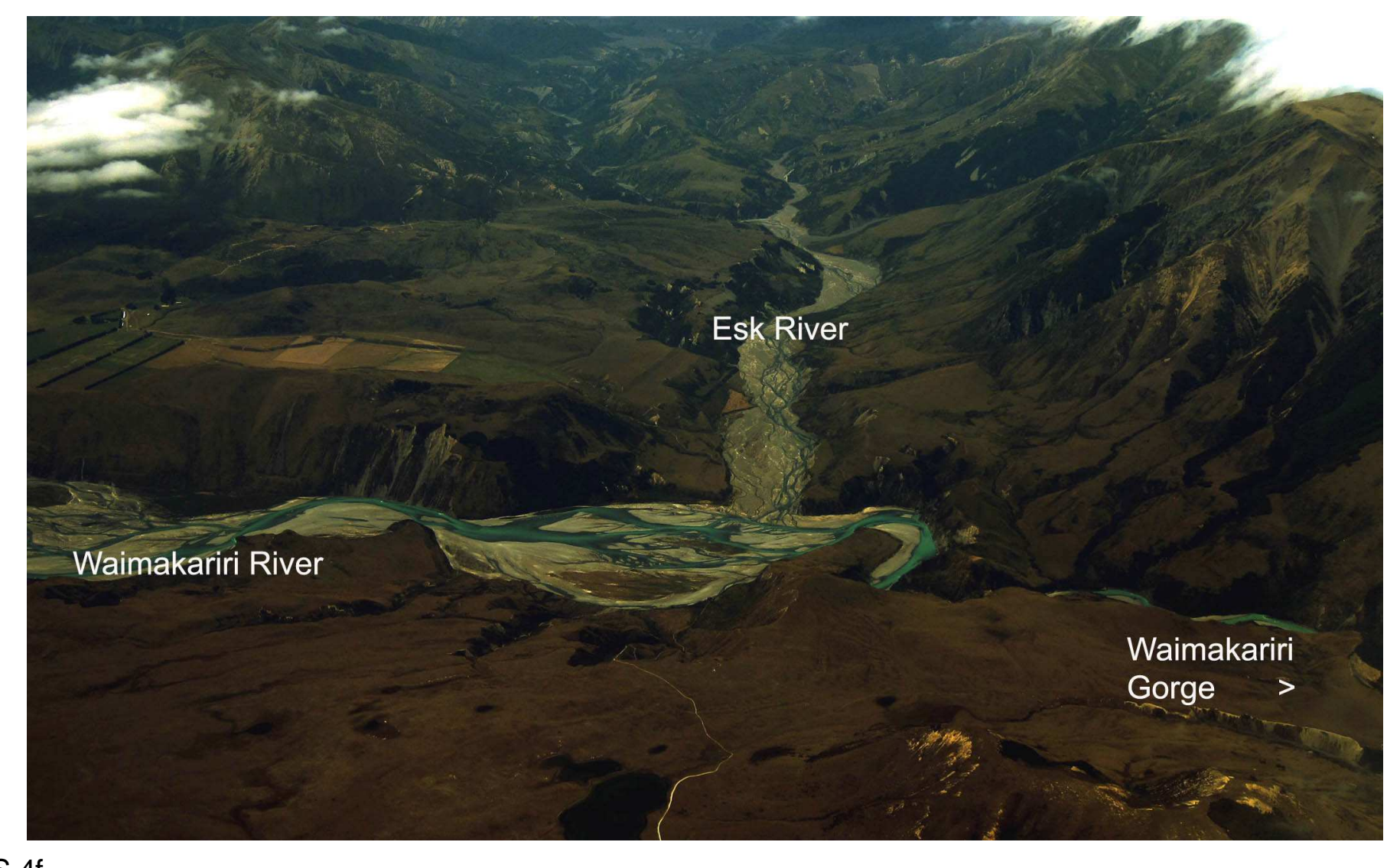

S $4 f$ 